DOI: https://doi.org/10.24297/jssr.v15i.8679

\title{
Social Management as a Current Challenge for Management and Sustainability of Efficiency in Social Services
}

Lýdia Lehoczká

Faculty of Social Sciences and Health Care Constantine the Philosopher University in NitraUniversity in Nitra

Ilehoczka@ukf.sk

\begin{abstract}
The paper discusses the requirement to develop social management. It specifies the strategic and current intention for social services and emphasises its contribution to improving the quality of professional and managerial activities in this field and the sustainability of efficiency. The study states the major research findings identifying the essential elements of management in the statements of future professionals in social services through the acquisition of important competencies and the overall professionalization of their field.
\end{abstract}

Keywords: Social Management. Social Services. Social Capabilities. Management. Efficiency. Quality.

\section{Introduction}

The issue of social management in social services has become topical, and its importance is emphasised by the fact that it is a fundamental prerequisite for the professional performance of providing this form of social assistance to individuals, groups, and communities in a difficult social situation. Social services are a dynamically evolving social area with the considerable heterogeneousness of their target groups, which increases the difficulty of social management at various levels of management (national, regional, local) throughout the system of its practical implementation. The experts in social services witness that social management is still not sufficiently developed, and, for the practice of their performance, new management approaches need to be introduced to promote the sustainability of efficiency of professional and service activities that define social services. Development of social management in social services benefits from the papers by Strieženec (2001); Matoušek (2003); Mydlíková (2004); Bernhart s kol. (2006); Dudinská a kol. (2009); Fabiánová (2010); Hangoni, Imrichová (2010); Repková (2000); Vaverčáková, Hromková (2018); etc. as well as the papers on management of other human activities (more generally): Vodáček, Vodáčková (2013); Blažek (2014); Sedlák, Lišková (2015); Majtán a kol. (2016); etc. Balance of the economic, social and psychological factors in the social services management was stated by Vaverčáková, Hromková (2018, p. 8-9) who emphasize that when studying management, it is important to realise that the concept of management can be understood and interpreted in four meanings (process, profession, scientific discipline, and art). In the study, we focus on social management as a dynamic and repetitive process that is characterised by the above-mentioned authors as an approximation of the manager's practical activity which consist of a set of activities to achieve a goal, including their implementation and evaluation.

\section{In the theoretical models of management, there are:}

- The classical school - the foundations of scientific management, the corporate level of management with the representatives (Taylor - systematic training of the staff; Fayol - defining five functions of management: planning, organising, commanding, coordinating, and controlling; Weber-notion of power);

- The behavioural school - the focus is on human resources, human relationships and people's behavior with the representatives (Mayo - psychological and sociological aspects of management; McGregor - Theory $X$ and Theory Y; Maslow - meeting human needs, using them for the motivation of people); and

- The quantitative school - mathematical approach to management with the representatives (Churchman the use of cybernetics and computing; Ackoff - algorithms in the management of organizations); etc. 
The five main management functions must be maintained, met, and developed. The present study discusses the management and sustainability of efficiency in social services; our intention is to highlight the potential of social management in its fourth generation - according to a historic and developmental perspective. The importance of social management is also projected to meeting the quality in the provision of social services with a system approach preference, as a basis for modern management theories. The system school (Ludwig von Bertalanffy, 1972) provides a more comprehensive management theory. The system approach allows a holistic, comprehensive understanding of the phenomena and processes considered in all their essential internal and external contexts. It is a way of thinking, problem-solving, and action, in which we can understand the phenomena comprehensively in their mutual contexts. It creates an appropriate basis for answering questions such as: What should be a priority in providing social services - the quantity of professional and service activities or their quality? What would social care receivers prefer? What are the possibilities for operationalisation of the concept of efficiency (effectiveness, or profitability) in social services if a profit is not a priority? In our opinion, the ability of the activity and its sustainability in social services can be related both to quality and quantity. However, it is possible when maintaining the professional efficiency of this social assistance in all managers (directors, managers, leaders), as well as in professional staff (key staff, main positions) who manage their colleagues at some level. Currently, the system approach is one of the main trends in social sciences (Schlippe, Schweitzer, 2001). It is based on the idea that a professional is part of a helping relationship and influences it. The role of communication with the receiver is emphasised. We do not only perceive the problems of the receiver of social services from his internal (psychological) factors, but they are also influenced by the environment (Gjuričová, Kubička, 2003; Jonesová, 1996). We do not look for causes of a problem of a social service receiver that cannot be determined. We assume that problems arise in human relationships and are perceived as the consequences of the chaining of various circumstances (Schlippe, Schweitzer, 2001). An important concept is a "system created by a problem".

In the approach, the receiver is perceived as autonomous and competent to solve a problem; his activity, initiative, and responsibility for change are emphasised. A professional functions as a facilitator that activates the unused resources of the service receiver and, together with the client, seeks alternative solutions (Ludewig, 2011). Mediation is another specific service focused on finding solutions to problems involving all parties in the social area (Vanková, 2016).

In providing social services, staff's professionalism and interest in the overall professionalisation of social services, also through the development of social management, are important. "The identified central elements of interest in social management are social knowledge, social skills, and social contacts; they are the basis of the social management scheme and provide the systematising unit necessary for the comprehensive grasp of the management processes in social work" (Fabiánová, 2010; translated by the study author), which we also acknowledge in social services. It is also necessary for managers to be able to present their objectives correctly, and thus allow their staff to meet them successfully. Social services include not only management but also other activities: strategic (planning), coordination, intervention, counselling, therapeutic, preventive, crisis, diagnostic, rehabilitation, assessment, nursing, organisation, and research activities. Qualification training for the helping profession requires the acquisition of theoretical and practical skills and competencies in order to achieve the professionalism of its performance, i.e. the proper implementation of the activities associated with the profession with the most prominent level of sustainability of efficiency.

The aim of the personality development of an aspirant in this helping profession is to achieve the competency to perform their future profession while complying with the principles of social services activities: preserving human dignity of a receiver of a given social service, support for his independent life, overcoming a difficult social situation, and eliminating the social exclusion of individuals, groups, and communities. It is also important to prepare them to support the activity and autonomy of the receiver of the social service, and to respect their choice, independent decision making, and the specificity of their needs. According to Rusnáková (2015); and Rosinský, Čerešníková, Rusnáková (2014), considering the specificity of the needs is important for educational work with marginalised communities. 
In the general overview, we state the following necessary competencies: interaction, communication, behavioral, and organisational (Řezáč, 1998). In particular, the acquisition of key competencies is important for the professional performance of a given profession. They are knowledge competencies that a university graduate acquires through knowledge from various scientific disciplines. Furthermore, they are competencies of subjective evaluation (efforts to continually improve one's own performance and objective self-assessment), or professional, cooperative, and communication competencies.

Competencies express how a person should behave to perform (hold) his post competently. In social services, the starting point is a flawless process of processing the social information, which leads the professional to the selection of a correct, appropriate method (approach), its specificity (Barlett, 2002), and the overall knowledge of the methodology of assistance.

Social capabilities of social services professionals should be developed in a specific situational context of the client/user. Also, one of the tools for the development of professional competencies in the helping profession is a theoretical training. Výrost (2002, in Hupková 2011, p. 18) states that social competency is situationally specific and contingent on ontogenetic aspects. Its content consists of several components, including decisionmaking ability, constructive conflict resolution, effective communication in various relationships and situations, the ability to make and maintain relationships, and orientation to the future, which are particularly important for management.

Social services are closely related to needs. Their identification, objectification, and legitimacy are important for all levels of management of the social assistance system. In social management, it is particularly necessary to know and work with the (recipients of services and staff's) needs analysis techniques at the level of a specific organisation. They include, for example, the diagnosis of an organisation, benchmarking, surveys on attitudes and atmosphere of the organisation, programmes on reforms and efficiency improvement, analysis of future trends, audits of (management) development, and others. Selection of a particular technique should take into account the dimension of the detected needs and also a confirmation of the correctness of the choice by the manager.

\section{Methodology}

An important part of social management in social services is the knowledge of the methodology of assistance and its praxeological implementation. Respecting the required assistance procedure is a prerequisite for the success of the professional not only in the management position, but also others, with the help of specific laborprofessional social capabilities. Social services, as a helping profession, require education also in the academic environment, focused particularly on the development of social capabilities, which are developed based on sociability, and also the development of managerial competencies. The efficiency of professional and service activities in social services is based on defining the organisation's objectives. They should be explicitly formulated, viable, and recognizable by both the staff and the receivers of the social service, which facilitates their achievement. Other essentials such as material, technical, and overall operating conditions for the provision of social services are also needed. Effective social management also uses regular supervision.

The above-stated social competencies related to work activity represent a set of professional skills and competencies that enable an individual to perform their work tasks and pursue the profession. They express how a person should behave to perform (hold) his post competently. The starting point is flawless processing of the social information, which leads the professional to the selection of a correct, appropriate method, approach, (Barlett, 2002), and the overall knowledge of the methodology of assistance. Our study, which exhibits a comparative form using the qualitative methodology, focuses on identifying the prerequisites for the professionalisation of social services by future professionals (university students in two V4 countries: Slovakia and Poland) at the second stage of education, with the possibility of applying to management posts. In the European Union countries, in the field of social services, there is an open method of coordination as a voluntary instrument for intergovernmental cooperation between the Member States. Its aspiration is the assistance to meet the objectives of the Lisbon Strategy and the Strategy 2020, which allow the Member States to share their 
experience in the areas of common interest. One of the possibilities to meet the objective is the comparison of training programmes, their evaluation, or sharing the knowledge of future professionals.

\section{Results and Discussion}

The data that we obtained from the students also gives us feedback on the content of education in a given field/study programme, as one of the ways to develop their competencies also in the managerial activity. Our study was conducted from 2/2018 to 6/2018 (the Polish University environment) and from 11/2018 to 2/2019 (the Slovak University environment). The main objective of the present study is the description of the knowledge of the Polish and Slovak participants, related to the conditions for the professionalisation of their future helping profession. In interpreting the results, we focus on selecting the data we gained in relation to social management and the prerequisites for the sustainability of the efficiency of the activities. The main method of collecting the empirical data of the research project consists of 24 essays on the topic. We used a technique of qualitative analysis of the text in order to reveal the relationships with the professionalisation of their profession in analysing the essays through which we obtained the data, and we used the techniques of categorisation and coding in analysing the empirical material. We used open coding for the participants' statements and sorted them into thematic groups based on their content and identified relatedness to the main content categories created. Individual levels of professionalism (academic, scientific, practical) were found in them.

\section{Major Findings:}

The students were able to express the prerequisites for the professionalisation of the studied profession as follows. In particular, they linked the theory to knowledge from multiple social and scientific disciplines, highlighting the interdisciplinarity and multidisciplinarity. Specifically, they stated the necessity of knowledge on law, psychology, social policy, social work history, and methodology (research). For the practical performance of the profession, the participants emphasised: personality predispositions; the attainment of the level of being an expert; respect the specificity of the profession; stress resistance; a high degree of personal sophistication of the professional; the use of knowledge - methodological, managerial, legal - and decision making; constant enhancement of knowledge and skills; the required level of education; teamwork; the importance of skills and capabilities; flexibility; active listening; the ability to react in a crisis and stressful situations; a sensitive perception of needs of individual target groups; the acquisition of the principles of ethics; and respecting the client.

\section{Conclusions}

In the text segments, we identified several important components for the performance of managerial activities. In the participants' statements, the essential elements of social management, in particular, social knowledge and skills were saturated - related to the content. In an educational process for future helping professionals, attention should be paid to the fundamentals of management in general, as well as its specific form for the performance of a particular profession as a contribution to the sustainability of management and efficiency of its practical implementation. For social services, it is important to prepare the graduates for professional and managerial activities that can be carried out on various positions in government organisations, municipalities, public institutions and services facilities for the benefit of individuals, groups, and communities in a difficult social situation.

\section{References}

1. Bartlett, J. (2002) Using Risk Concept Maps in a Project or Programme. Proceedings. ISBN 978-1-900391$17-7$.

2. Bernhart, J. s kol. (2006). Innovazioni nelmanagement sociale. Milani: Franco Angeli. ISBN 3-7065-4190-4.

3. Bertalanffy, L. (1972). Člověk - robot a myšlení: Psychologie v moderním světe. Praha: Svoboda.

4. Blažek, L. (2014). Management.Praha: Grada. ISBN 978-80-247-4429-2. 
5. Dudinská, E. a kol. (2009). Manažment vsociálnych službách. Prešov: vydavatel'stvo Michal Vaško. ISBN 978-80-7165-756-9.

6. Fabiánová, M. (2010). Teoretické aspekty manažmentu v sociálnej práci verzus sociálny manažment. https://www.prohuman.sk/socialna-praca/teoreticke-aspekty-manazmentu-v-socialnej-praci-verzussocialny-manazment

7. Gjuričová, Š., Kubička, J. (2003). Rodinná terapie: systémické a narativní př́istupy. Praha: Grada. ISBN 97880-247-6980-6.

8. Goga, M. (2000). Kvantitatívny manažment. Bratislava: IURA EDITION. ISBN 80-88715-85-7.

9. Hangoni,T., Imrichová, A. (2010). Manažment a jeho aplikácia v sociálnej praci DATAPRESS, s.r.o. ISBN 978-83-928613-4-8.

10. Hupková, M. (2011). Rozvíjanie sociálnych spôsobilostí v pomáhajúcich profesiách. IRIS. ISBN 9788089256617.

11. Jonesová, E. (1996). Terapie rodinných systemů. vývoj v milánských systemických terapiích. Hradec Králové. Konfrontace.

12. Ludewig,K. (2011). Základy systemické terapie. Grada. ISBN 9788024735214.

13. Matoušek, O. (2003). Metody a ř́zení sociální práce. Praha: Portál. ISBN 80-7178-548-2.

14. Majtán, M. a kol. (2016). Manažment. Bratislava: Edícia Economics. ISBN 978-80-89710-27-0.

15. Mydlíková, E. (2004). Manažment vsociálnej práci. Bratislava: Občianske združenie Sociálna práca. ISBN 80-89185-04-5.

16. Repková, K. (2000). Projektovanie vsociálnej práci, stratégie, koncepčné východiská i praktické otázky. Bratislava: Epos. ISBN 80-8057-310-7.

17. Rusnáková, J. (2015). Economical exclusion and indebtedness as a financial strategy of poor roma households in Slovakia. In: Journal of Applied Economic Sciences. ISSN 1843-6110, Vol. 10, no. 7 (2015), p. $1145-1152$.

18. Rosinský, R., Čerešníková, M., Rusnáková, J. (2014). Intercultural Education in Elementary Schools in Slovakia. In: ICERI 2014: 7th International Conference of Education, Research and Innovation Seville - 17th19th November 2014. Valencia: IATED Academy. ISBN 978-84-617-2484-0. ISSN 2340-1095, P. 4401-4409.

19. Řezáč, J. (1998). Sociální psychologie. Nakladatel: PhDr. Vladimír Jůva,CSc.- PAIDO. ISBN 8085931486.

20. Sedlák, M., Lišková, C. (2015). Manažment. Bratislava: Edícia Ekonómia. ISBN 978-80-8168-296-4.

21. Schlippe, A., Schweitzer, J. (2001). Systemická terapie a poradenství. Cesta. ISBN 9788072950133.

22. Strieženec, Š. (2001). Úvod do sociálnej práce. Trnava: Tripsoft, 2 vydanie. ISBN 80-968294-6-7.

23. Vanková, K. (2016). Study of Civil Dispute Resolutions by Social Mediation Services in Civil Law. In. 4th icCSBs: Proceedings Book from Annual International Conference on Cognitive-Social, and Behavioural Sciences, Kyrenia, Cyprus, 10-12 May 2016. Nicosia: Future Academy. ISSN 2357-1330, online, p. 76-89.

24. Vaverčáková, M., Hromková, M. (2018). Manažment vsociálnej práci. Fakulta zdravotníctva asociálnej práce Trnavskej univerzity v Trnave. ISBN 978-80-568-0136-9.

25. Vodáček, L., Vodáčková, O. (2013). Moderní management vteórii apraxi. Tretie rozšírené vydanie. Praha: Management Press. ISBN 978-80-7261-232-1. 